\title{
THE WAYS OF CREATING PUBLIC PERCEPTION OF CCS-TECHNOLOGIES IN RUSSIAN FEDERATION
}

\author{
Yurii VASILEV \\ Saint-Petersburg Mining University, Department of Organization and Management; \\ Vasilev_YuN@pers.spmi.ru, ORCID: 0000-0002-5843-9353
}

\begin{abstract}
Purpose: to determine the ways of widening the public awareness of CCS technologies and, therefore, creating some level of public perception

Design/methodology/approach: The method of achieving the goals and tasks of this article is the secondary research of articles of foreign researchers related to formation of public opinion on climate change mitigation in general and, in particular, development of CCS projects. Besides, it is necessary to review Russian school textbooks to find the information about climatic problems.

Findings: It is necessary to review the experience of foreign countries to determine the ways of shaping public opinion on the climate change issues and decreasing the level of $\mathrm{CO} 2$ in the Russian Federation.

Originality/value: The article shows the major results of the survey: awareness of high environmental risks lowers public acceptance, the government plays a key role in environmental management, traditional and electronic media information can lower the perceived risk and improve the public acceptance of CCUS.
\end{abstract}

Keywords: carbon dioxide; carbon storage; climate; public acceptance; public awareness.

Category of the paper: General review.

\section{Introduction}

In response to human activity, the chemical composition of the atmosphere has changed due to accumulation of greenhouse gases such gases as carbon dioxide $\left(\mathrm{CO}_{2}\right)$, methane $\left(\mathrm{CH}_{4}\right)$ and oxide diazotate $\left(\mathrm{NO}_{2}\right.$, nitrous oxides). Hydrofluorocarbon and perfluorocarbon compound, sulphur hexafluoride $\left(\mathrm{SF}_{6},\right)$ and nitrogen trifluoride $\left(\mathrm{NF}_{3}\right)$ are the main greenhouse gases including water vapor $\left(\mathrm{H}_{2} \mathrm{O}\right)$ which is the prevailing greenhouse gas on the Earth.

The major target of climate change mitigation is to reduce greenhouse gases (GHG) emissions while maintaining high level of living standard and industrial and economic development. The main ways of reducing GHG emissions are the following: 
- decreasing energy consumption and increasing energy efficiency technology,

- transition from non-renewable energy to renewable one,

- replacement of fuel types in power industry (transition from coal to gas),

- carbon dioxide capture and storage (CCS technology).

Carbon sequestration or CCS (carbon capture and storage) technology is the process consisting in carbon capture and the long-term storage of carbon dioxide and other forms of carbon in geological traps.

Carbon sequestration technologies include capture, transportation, compression to the critical state and injection of carbon dioxide into underground reservoirs (often called geological traps). Several types of geological traps could be used for underground storage of $\mathrm{CO}_{2}$ : deep aquifers (salt formations), mature and depleted oil and gas fields, and undeveloped coal beds. The traps differ in capacity and preferred application.

Today more than 30 countries across the world deploy or plan to deploy about three hundred projects of carbon capture and storage (Romasheva et al., 2018).

Table 1 contains data about CCS projects deployment worldwide.

Table 1.

Global scale CCS-projects data

\begin{tabular}{|l|c|}
\hline \multicolumn{1}{|c|}{ Project features } & Projects number \\
\hline Total number & 299 \\
\hline technology subdivision: & 76 \\
$\mathrm{CO}_{2}$ capture projects & 76 \\
$\mathrm{CO}_{2}$ storage projects & 147 \\
$\mathrm{CO}_{2}$ capture and storage projects & 36 \\
\hline stage subdivision: & 93 \\
planned for deployment & 58 \\
operating & 35 \\
postponed by managerial decision & 77 \\
suspended & 36 \\
completed & \\
\hline
\end{tabular}

Source: compiled by the author using (Romasheva et al., 2018).

As it can be seen in Tab. 1, about $50 \%$ of projects provide both carbon dioxide capture and storage while there is an equal share $(25 \%)$ of projects providing only either carbon dioxide capture or storage. It is noteworthy that the share of operating projects is relatively low $(41 \%)$. It is equal to the share of suspended or postponed projects. 26 percent of projects are completed ones.

Currently in the Russian Federation there are no projects of $\mathrm{CO}_{2}$ sequestration even at an early stage of planning.

However, in the Russian Federation there are some prospects for carbon capture and storage technologies development and deployment. They are caused by a number of factors. Firstly, there are some oil and gas deposits with high rate of oil and gas depletion (the VolgaUral, West Siberian, North Caucasian and Mangyshlaksky oil and gas basins). Secondly, some regions of the Russian Federation are characterized by suitability in implementing such projects 
(The Republic of Bashkortostan, the Republic of Tatarstan, the Tyumen region, Kuzbass). There is a number of restrictions not allowing to carry out a large-scale deployment project in a short term. However, according to our opinion, positive performance of CCS projects increases momentum for deployment (Cherepovitsyn, 2015; Cherepovitsyn, and Chvileva, 2018; Khlebnikov et al., 2009).

Both Russian and foreign scientists highlight that public environmental awareness can be created in the process of communication allowing to form a certain level of environmental knowledge and it can be changed by providing news information. In the 21 st century news media play a significant role in informing the public of environmental problems. The media's primary responsibility is to educate the public about the threats to the environment posed by climate change and GHG emissions. Media coverage should also inspire efforts towards energy saving and alert the public about the consequences of anthropogenic climate change. Thus, media have the most powerful informational impact on frame and reflect public discourse in the Russian society (Korunova, 2017).

In different countries of the world the study of public perception on CCS projects feasibility has received most of its attention recently. Some countries such as Australia, Great Britain, China, Romania, the USA, Japan and other provide researches related to framework of communication strategy for shaping public perception concerning deployment of CCS technologies (Anghel, 2017; Feldpausch-Parker et al., 2015; Gough et al., 2017; Li et al., 2017; Sacuta et al., 2017; Saito et al., 2018).

It is noteworthy that there are some Russian researches devoted to CC technologies. Thus, A. Cherepovitsyn developed the typology of instruments for promoting technologies of carbon dioxide capture and storage particularly including a number of public events. Among them we can define the following: public promotion of nature protection technologies; providing environmental knowledge for future generations to control and prevent of tremendous negative consequences (Cherepovitsyn, 2015). Telegina E.A. and Tyrtyshovoy D.O. stress the importance of communication between social and political stakeholders to support decarbonization and long-term prospects of using natural gas on the key sales markets (Telegina, and Tyrtyshova, 2017).

The objective of the article is to determine the ways of widening the public awareness of CCS technologies and, therefore, creating some level of public perception.

\section{Methods}

It is necessary to review the experience of foreign countries to determine the ways of shaping public opinion on the climate change issues and decreasing the level of $\mathrm{CO} 2$ in the Russian Federation. 
The method of achieving the goals and tasks of this article is the secondary research of articles of foreign researchers related to formation of public opinion on climate change mitigation in general and, in particular, development of CCS projects. Besides, it is necessary to review Russian school textbooks to find the information about climatic problems.

On the basis of the obtained information we can propose public events aimed at increasing public awareness of climate change mitigation and shaping public perception of CCS projects to decrease anthropogenic impact on environment.

\section{Results}

Scientists tackling the issues of informing stakeholders on CCS projects created a multilevel communication strategy targeting particular levels of stakeholders (Table 2). The proposed communication strategy was developed by the Australian researchers but it can be implemented in other countries.

Table 2.

Multi-level approach to the stakeholders targeting

\begin{tabular}{|l|c|}
\hline \multicolumn{1}{|c|}{ Level } & Kind of communications \\
\hline Landholders & Personal contact; Relationship building \\
\hline Community consultative committee; Neighbours & Personal contact; Publications; Meetings \\
\hline Local community & Informational sessions; Publications; Local media \\
\hline Schools & CarbonKids workshops; Science Expos \\
\hline Regional community & $\begin{array}{c}\text { Agricultural shows; Regional media; Web-cites; State- } \\
\text { wide media }\end{array}$ \\
\hline National and international CCS community & National media; Conferences; Specialized data via \\
Websites
\end{tabular}

Source: compiled by the author using (Ferguson and Van Gent, 2017).

As a result of the stakeholders interviewing in the UK it was found out that they identify significant economic benefit of CCS project deployment for the area in the terms of encouraging investment and raising local employment opportunities (Gough et al., 2017). But it should be highlighted that all the stakeholders are more focused on implementing fracking for shale gas exploration than CCS projects as it remains less popular technology among local community.

In the long run the interviewing of the focus groups revealed controversial approach to CCS projects deployment. Initially the Lancashire and national stakeholders expressed concerns about possible leakage of stored CO2. But the stakeholders in the Teeside region were optimistic about Teeside CCS project deployment due to the regional employment opportunities. Furthermore, CCS technologies were seen by respondents as an essential stage of local industry development. 
In Canada and nearby there are three CCS projects:

- the Aquistore project (a deep saline storage project operating in Canada),

- the Bell Creek in the United States,

- Weyburn oil field in Canada.

Within public communications framework of the project deployment there is a possibility to accommodate sufficient numbers of tour requests and presentations on the project's research findings (no less than 120 tour requests per year). Moreover, they provide national and international stage initiatives (Sacuta et al., 2017):

- a public display on the science of $\mathrm{CO}_{2}$ storage at the Weyburn project at Weyburn City Hall,

- the development of an educational website about $\mathrm{CO}_{2}$ storage for a wider Canadian and international audience that would also provide important information,

- presence at conferences within Canada and internationally, both to promote the CCS website and disseminate research findings from the Weyburn project to scientific and educational audiences,

- arranging for editing and publishing three publications to disseminate the WMP results to the scientific community.

In the course of the study on public awareness of CCS technologies in Romania it was revealed that the vast majority of respondents (just over 75\%) indicated never having heard of CCS technologies. Moreover, the research showed respondents' dependence on gender and educational level. Thus, male respondents indicated higher level of awareness of CCS technologies in comparison to female ones. It is a remarkable fact that the higher level of education respondents have, the more informed they are about CCS technologies (Anghel, 2017).

Overall, Romanian respondents have positive approach to future opportunities of CCS projects deployment.

According to the survey results carried out in Japan in 2015, more than $50 \%$ of respondents have poor knowledge on CCS technologies, about $40 \%$ of them have heard about it while only $7 \%$ of community 'know' and 3\% 'know well and could explain' about CCS technologies (Saito et al., 2018).

Generally the study shows that CCS technologies are not regarded as a crucial method for reducing carbon dioxide emissions in Japan. The majority of Japanese respondents identifies CCS technologies development with future power generation. Thus, they suppose that improving energy efficiency could cause CCS projects deployment mostly in Japan and not in the rest of the world.

The Chinese researchers conducted a large national survey on public awareness of the environmental impact and management of CCUS technology (carbon dioxide capture, utilization and geological storage) in 2013, focusing on people having or getting tertiary 
education. Thus, they interviewed 563 respondents (353 full time and part time students; 73 company employees; 26 CCUS industry personnel; 15 self-employ or freelancers; 11 public servants; 2 retired or unemployed; 83 other). The results of the study revealed that $26,7 \%$ of respondents had not heard anything of CCUS; 44\% knew a little; 22,9\% knew about CCUS; $6,1 \%$ knew much. The survey indicated the following responses to the question "Are you interested in CCUS technology?": 19,7\% of interviewees responded "very interested"; $54,6 \%$ were "more interested"; 20\% - "little interested"; 3,2\% - "not interested"; 2,5\% - "do not know".

The major results of the survey:

- awareness of high environmental risks lowers public acceptance,

- the government plays a key role in environmental management,

- traditional and electronic media information can lower the perceived risk and improve the public acceptance of CCUS (Li et al., 2017).

\section{Discussions}

As it was mentioned above, currently in the Russian Federation there is no communication system for shaping public perception of decreasing carbon dioxide and spreading information of CCS technologies.

The issue of environmental education is discussed within the framework of school training. The research of Russian school textbooks contents showed that much attention is paid to the protection of air and water pollution within the curriculum of "Social science" in primary school. The "Ecology" textbook of the 9th class contains the topic "Problem of Greenhouse Effect" which discusses the paramount value of decreasing $\mathrm{CO} 2$ emissions to prevent average air temperature increase. It also points out the changes in world power system. Students of 10th-11th class study the information of catastrophic environmental impacts of increasing average annual temperature in the lower layers of the atmosphere in the framework of the course "Fundamentals of Ecology".

However, Russia lacks the organizational instrument of public awareness formation currently.

For actions aimed at increasing public awareness of CCS technologies it is possible to recommend the experience of Japan. They created a series of comic books for children and adults "CCS Cartoons to save our Earth" within the framework of CCS project "Tomakomai" for strengthening public ties. In Australia the program "Sustainable Futures-CarbonKids" has been developed and its purpose is to increase school students' awareness of CCS projects (Bloxsome et al., 2017). 
It is necessary to arrange a number of events to increase public awareness of CCS technologies at the level of preschool and school training in the Russian Federation:

- Holding seminars and colloquiums on the topics related to circulation and need of capturing greenhouse gases including carbon dioxide,

- Including information on the greenhouse gases and environmental problems caused by them and how it is possible to tackle the matter in various books for children (books, encyclopaedias),

- Carrying out experiments to study permeability of various rocks as well as $\mathrm{CO}_{2}$ capture from carbonated drinks at school lessons of Chemistry and World Around,

- Producing educational videos on the topics "Carbon on Earth", "Carbon Issues", "Frightening Carbon", "Carbon Capture"

- Issuing popular scientific editions on the topics related to global warming and its prevention.

Implementation of the proposed events requires investments in such projects. The main volume of such investments has to be covered by the state. Power generating companies and mining companies can provide investment in the regions which are the most suitable for CCS projects implementation.

It is worth including lecture materials and practical tasks devoted to issues of GHG decreasing, in particular, $\mathrm{CO}_{2}$ emissions in curriculum of higher educational institutions for such disciplines as "Ecology", "Ecology of megalopolises", "The systems of providing environmental safety", "Recycling of industrial and household wastes".

According to our opinion, the most important thing is to develop evaluating methodology of public efficiency of CCS projects. This solution has to include such matters as studying a degree of public awareness of CCS technologies in the Russian Federation. It considers positive and negative aspects of CCS projects, taking into accounting stakeholders' interests, adoption of additional normative legal acts in the given and accompanying fields.

\section{Conclusions}

Scientists across the world are focused on the issues of studying public awareness and perception of climate change and operating CCS projects currently. Within the framework of these researches a number of activities are provided, both informational and experimental ones (Canada). Some countries (the USA, Romania, Japan, China, etc.) study public awareness of CCS technologies.

The researches show that some countries indicate rather low level of public awareness of CCS technologies in general. Communication strategy for improving public awareness is developed in a number of countries providing CCS projects deployment. 
Foreign researchers stress that there is no public environmental awareness in Russia despite visible signs of the climate change phenomenon (increasing average winter temperature in the Arctic zone of Russia by more than 3 degrees, reducing snow and ice coverage, flooding risk of coastal areas, etc.). The Russian mass media do not provide efficient and effective coverage of climate change issue. Both scientists and policy makers do not pay much attention to the problem of global warming.

Despite the above-mentioned statement, we can observe positive movements concerning climate change mitigation.

Nowadays forming an educational and enlightenment system for increasing the level of knowledge on CCS-technologies is very important for Russian Federation. This system must include three levels: pupils, students, adults. Our potential research direction is to develop activities for building the educational and enlightenment system.

\section{Acknowledgements}

The research is carried out with the financial support of the grant of the Russian Science Foundation (Project No. 18-18-00210, "Development of assessment methodology of public efficiency of projects devoted to carbon dioxide sequestration").

\section{References}

1. Anghel, S. (2017). Impact of CCS communication on the general and local public in Romania- Oltenia region. Energy Procedia, 114, 7310-7316.

2. Bloxsome, B. (2017). A collaborative approach to school community engagement with a local CCS project. Energy Procedia, 114, 7295-7309.

3. Cherepovitsyn, A.E. (2015). Economical and social aspects of development of technologies of capture and burial of $\mathrm{CO}_{2}$ in an oil and gas complex of Russia. Journal of Mining Institute, 211, 125-130.

4. Cherepovitsyn, A.E., and Chvileva, T.A. (2018). System of public perception of carbon dioxide sequestration projects. International Journal of Civil Engineering and Technology, 9(12), 62-69.

5. Feldpausch-Parker, A.M., Burnham, M., Melnik , M., Callaghan, M.L., and Selfa, T. (2015). News Media Analysis of Carbon Capture and Storage and Biomass: Perceptions and Possibilities. Energies, 8(4), 3058-3074, DOI:10.3390/en8043058. 
6. Ferguson, B., and Van Gent, D. (2017). A multi-level, multi-platform approach to communications on the South West Hub CCS project. Energy Procedia, 114, 7260-7275.

7. Gough, C., and Cunningham, R., and Mander, S. (2017). Societal responses to CO2 storage in the UK: media, stakeholder and public perspectives. Energy Procedia, 114, 7310-7316.

8. Khlebnikov, V.N., Zobov, P.M., Hamidullin, I.R., Ruzanova, Y.F., Ivanov, E.V., and Vinokurov, V.A. (2009). Перспективные регионы для осуществления проектов по хранению парниковых газов в России. Bashkir chemical journal, Russia, 16(2), 73-80.

9. Korunova, N.O. (2017). Специфика экологической информации в СМИ как средства конструирования экологического сознания россиян. Obschestvo: sociologia, psihologia, pedagogika, 7, 45-47.

10. Li, Q., Liu, G., Leamon, G., Liu L., Cai, B., and Chen, Z. (2017). A national survey of public awareness of the environmental impact and management of CCUS technology in China. Energy Procedia, 114, 7237-7244.

11. Romasheva, N.V., Kruk, M.N., and Cherepovitsyn, A.E. (2018). Propagation perspectives of $\mathrm{CO} 2$ sequestration in the world. International Journal of Mechanical Engineering and Technology, 9(11), 1877-1885.

12. Sacuta, N., Daly, D., Botnen, B., and Worth, K. (2017). Communicating about the geological storage of carbon dioxide - comparing public outreach for $\mathrm{CO}_{2} \mathrm{EOR}$ and saline storage projects. Energy Procedia 114, 7245-7259.

13. Saito, A., Itayoka K., and Akai, M. (2018.10.21). Those who care CCS - Results from Japanese Survey on Public Understanding of CCS. 14th International Conference on Greenhouse Gas Control Technologies, GHGT-14, Australia.

14. Telegina, E.A., and Tyrtyshova, D.O. (2017). Природный газ в условиях декарбонизации Европейского энергетического рынка: факторы ограничения и меры адаптации. Oil, gas and business, 11, 38-43. 